\title{
Older, How? The Importance of Practising Educative and Healthy Activities
}

\author{
María José Flores Tena ${ }^{1}$ Carlos Sousa Reis ${ }^{2}$ \\ ${ }^{1}$ Departamento de Pedagogía de la Facultad de Educación de la Universidad Autónoma de Madrid, \\ Madrid, España.maria.flores@uam.es \\ ${ }^{2}$ Universidad Coimbra, Facultad de Educación, Rua do Colégio Novo 3000-115 COIMBRA, Portual. \\ csreis.uc.pt
}

Article History: Received: 10 November 2020; Revised 12 January 2021; Accepted: 27 January 2021; Published online: 5 April 2021

\begin{abstract}
This research aims to study active ageing by participation in educative and healthy activities (PE\&HA) at centres that provide active ageing programmes. An exploratory quantitative study was undertaken, envisaging to explore the relationship between certain variables (age, sex, attendance and type of activity) and the degree of satisfaction with PE\&HA. An intentional non-probabilistic sampling was applied to select 800 persons over 55, corresponding to users of various senior centres located in four districts of Madrid, Spain. The data collection instrument consisted of 29 easy-tounderstand questions grouped into six dimensions. Results of the questionnaire indicate that users are satisfied with PE\&HA offered by the centres. According to $78 \%$ of the respondents, the participation in workshops and other group activities contribute to a better quality of life in the elderly, and no statistically significant differences were found between the users' degree of satisfaction and gender. This research provides possible improvements in areas that will contribute to preventing dependence; for example, those in which there is a greater demand from users. As proposals for improvement, we suggest designing specific strategies to obtain more male participation in senior centre workshops.
\end{abstract}

Keywords

Active ageing, permanent education; life expectancy, leisure, free time.

\section{Introduction}

Greater longevity of the population is considered one of the defining characteristics of the 21 st century, which is reflected in the notable increase in the elderly population that has occurred in the last two decades [1]. Statistics issued by the United Nations (UN), in its report "World Population Prospects 2019", indicate that by 2050, $16 \%$ of the world's population, or one in six people, will be over 65 years old. This is an important increase compared to the year 2019, in which $9 \%$ or one in 11 people were over 65 years old. The UN also notes that by 2050 the number of people aged 80 or over will reach 426 million, a considerable rise in the existing 143 million by 2019 [1]. For this reason, international interest in measuring the quality of life of older adults has attracted strong interest, as well as the design of international action plans that could ensure the quality of life of older adults and better ageing. These plans take into account the things that older adults consider important in life, to align the objectives with the expectations of the beneficiaries [2]

Quality of life is a multidimensional issue. In the 60s, articles about life satisfaction were published, in the 70s the concept of quality of life emerged; and later in the 80s, the concept of subjective well-being became dominant [3]. Currently, there is interest in the concept of active ageing, which is accepted as an adaptation process through which optimal physical, psychological and social development is achieved [4]. Although some authors argue that there is no specific definition for active ageing [5], many agree that it is a multidimensional concept, which involves physical and cognitive fitness, social participation, health, affection 
and positive control $[5,6]$.

Active ageing requires the progress of society in political, social and cultural aspects; greater investment in social security, pensions and health systems; and a greater number of activities that promote a better quality of life, autonomy and health in older adults [6]. In Latin America and the Caribbean, countries such as Argentina, Mexico, Costa Rica and Uruguay have begun to evaluate the implementation of agreements in the areas of health, legislation, labour and social security, focusing on the elderly. These countries give great importance to healthy ageing and health in general, the aim being to provide a better quality of life through policies and programs. There is also a tendency to develop institutional environments that allow improving the self-perception of old age, as well as cultural, cognitive, physical and recreational activities.

In Europe, the concept of active ageing contains the idea that ageing involves, rather than the acceptance of dysfunctions and alterations associated with ageing, the optimization of the potentialities and possibilities of growth and personal development [7]. International and Spanish institutions demand the implementation of policies, initiatives and programs that improve health and well-being throughout life, allowing active ageing to be maintained and implemented as a routine [8].

Sociocultural animation is an educational practice that seeks to promote the integration and active participation of people, in search of their social development and a better quality of life [9]. [10] mentions the four fundamental pillars of the education of human beings, described by [11]: learn to know, learn to do, learn to live together and learn to be; indicating that these must be included effectively in educational environments so that education can evolve positively in the human being. Leisure, as a social and cultural element, does not remain foreign to such evolution and, in turn, contributes from the personal, social and economic point of view, to the configuration of certain habits, lifestyles, different ways of understanding rest and recreational development of new activities. [12] and [13] point out that active leisure generates expectations around healthy ageing, which is necessary for active ageing.

Currently, older adults have a greater social role, thanks to inclusion in the environment where they live and because they are recognized as people with abilities and potential that allow them to be active. Old age is an irreversible definitive state, a natural process of every living being [16] where each individual ages differently [17]. It is important to consider ageing and old age from a psychosocial perspective and not only from a biological perspective [7].

It is important to face old age through citizen participation in social centres where socioeducational activities can be developed [14]. In senior centres, it is perceived that many older women are afraid to give their opinion or explain their way of thinking since they easily fall into the inertia, routines and stereotypes of traditional social practices. Another major problem faced by older women alone regarding leisure is that they do not know how to use their free time [15].

The different activities carried out in the workshops and the experiences that arise from them form the non-formal permanent education space that gives meaning to leisure time in which music, education, and current debates are enjoyed, among others. The workshops aim to:

- Respond to demands.

- Coordinate professionals.

- Develop and promote active ageing programs.

- Provide knowledge.

- Promote social integration.

Regarding the relationship between personal perception of ageing and longevity, there is evidence that positive perceptions, attitudes and thoughts in the elderly increase their life expectancy [18]. On the contrary, discrimination based on perceived age tends to generate dissatisfaction and unhealthy sequelae in older adults [5].

In Spain, one of the challenges that our society must face to alleviate social inequalities in the coverage of the welfare and economic needs of the retired and elderly population. Such purpose entails preparation for the retirement of people between 55 and 65 years and, in parallel, the creation or development of resources for the occupation of free time [19].

In 2006, the Organic Law of Education in its Article 5 "Lifelong Learning", provided: 1) 
All persons must have the possibility of training throughout life, inside and outside the education system. 2) The educational system has as its basic principle to promote permanent education. 3) To guarantee universal and permanent access to learning, the different public administrations will identify new skills and provide the training required for their acquisition. On December of the same year, law 39/2006 [20] was approved, whose article 3 focuses on the promotion of personal autonomy and care for people in dependency. This law inspires the following principles, which take effect in Article 27 of the Constitution:

a) The universality in the access of all people in a situation of dependency, in conditions of effective equality.

b) Attention to people in situations of dependency in an integral and integrated way.

c) The participation of people in a situation of dependency and, where appropriate, their families and entities that represent them in the terms provided in this Law.

d) The inclusion of the gender perspective, considering the different needs of women and men.

Legal references aside, it is unavoidable to highlight several pedagogical milestones that have contributed to the conception of education throughout life, key in the process of active ageing. The World Health Organization (WHO) defines active ageing as the process of opportunities, in relation to the physical, social and emotional spheres, which improve the quality of life of the elderly [21].

In 2012, the European Year of Active Ageing and Intergenerational Solidarity was celebrated. In Spain, the organization was the responsibility of the Ministry of Health, IMSERSO. The activities covered different areas: awareness, training and information. Recently in 2017, the II International Congress "Active ageing, quality of life and gender" was held. This was divided into several modules or thematic tables: research and university, the participation of public institutions, participation in associations and program evaluation.

Therefore, ageing should not be considered a problem, but a challenge for everyone, both for society and for the ageing individual [22]. To achieve active ageing, it is essential to have a positive vision of ageing [23] which can be achieved through education and social participation [5]. This argument was considered essential for the development of this research, a perspective where older people have abilities and resources, where they are "subjects of the future, active protagonists, willing to redefine themselves through their ability to be mentally open to new experiences, to the changes and opportunities they can develop themselves" [24], p. 18. In any case, it is not about "prescribing" or "imposing" a unique pattern of active ageing, given the heterogeneity of ageing and the variability that exists in the way of ageing from one person to another. It should be noted that the educational activities must be developed in a consensual, reflective and dialogic way, based on the needs of the elderly and respecting their autonomy.

Among the PE\&HA, the centres offer a wide plethora of options: sewing and embroidery; Crafts; Chess; Encouragement to read; Ballroom dancing; Ribbon embroidery; Ceramic; Get to know Madrid; Coral; Cut and make; General culture; Digital photography; Gymnastics; Art History; Computer; Internet; English; Memory Activities; Field trips; Painting classes; Pilates; Laughter therapy; Taichi; Theater; and Yoga (Annexe 1).

This research aimed to find behaviours PE\&HA by persons older than 55 years of age. Which corresponds to the life period when one could start preparing its retirement, that can be anticipated to 60 years old, in Spain, and normally at 65 .

In this regard we envisage the following hypotheses:

$\mathrm{H}_{1}$ : There are significant differences between age groups regarding the attendance to PE\&HA.

$\mathrm{H}_{2}$ : There are significant differences between sexes regarding the attendance to PE\&HA.

$\mathrm{H}_{3}$ : There are significant differences between sexes regarding the type of activity attended in PE\&HA.

$\mathrm{H}_{4}$ : There are significant differences between age groups regarding the type of activity 
attended in PE\&HA.

$\mathrm{H}_{5}$ : There are significant differences between sexes regarding the reported satisfaction with the practising of PE\&HA.

$\mathrm{H}_{6}$ : There are significant differences between age groups regarding the reported satisfaction with the practising of PE\&HA.

\section{Methods}

\section{Subjects and Sampling}

The sampling was of a non-probabilistic-intentional type, in which four districts of Madrid were selected: Carabanchel, Tetuán, San Blas and Villaverde. Two hundred users from the senior centres were chosen from each district. A series of inclusion criteria were established, as is mentioned below: be at least 65 years old; be autonomous and physically able to participate in the activities carried out in the senior centres; be able to answer the questions of the questionnaire on its own.

The sample was made up of a total of 800 people over 65 years of age (Table 1), corresponding to users of senior centres located in four districts of Madrid. In the age groups created we can see that the great majority was aged between 65 and 74 (54\%). Although an important percentage of subjects was older than $74(18,6 \%)$. The younger participants, aged between 55 and 64, that we could consider to still be in so-called "active life", correspond to a small part of the overall $(7,9 \%)$.

Table 1. Age Groups

\begin{tabular}{|l|r|r|r||r|}
\hline \multicolumn{5}{|c|}{ GroupAge } \\
\hline \multicolumn{2}{|c|}{} & \multicolumn{2}{|c|}{ f } & \multicolumn{1}{c|}{$\%$ c } \\
\hline \multirow{4}{*}{$\begin{array}{l}\text { Vali } \\
\text { d }\end{array}$} & $55-59$ & 18 & 2,3 & 2,3 \\
\cline { 2 - 5 } & $60-64$ & 45 & 5,6 & 7,9 \\
\cline { 2 - 5 } & $65-69$ & 216 & 27,0 & 34,9 \\
\cline { 2 - 5 } & $70-74$ & 216 & 27,0 & 62,0 \\
\cline { 2 - 5 } & $75-79$ & 149 & 18,6 & 80,6 \\
\cline { 2 - 5 } & $80-84$ & 87 & 10,9 & 91,5 \\
\cline { 2 - 5 } & $85-80$ & 64 & 8,0 & 99,5 \\
\cline { 2 - 5 } & $>90$ & 4 &, 5 & 100,0 \\
\cline { 2 - 5 } & Total & 799 & 100, & \\
& & & 0 & \\
\hline
\end{tabular}

Globally, 487 cases $(61 \%)$ of the participants were females (Table 2). Which indicates that females are more prone to PE\&HA than men, which follows the population distribution in Spain, where there are more women than man.

Table 2. Sample description

\begin{tabular}{|c|c|c|c|c|}
\hline \multicolumn{5}{|c|}{ Sex } \\
\hline \multicolumn{2}{|c|}{} & f & $\%$ & $\%$ c \\
\hline \multirow{2}{*}{ Válido } & male & 312 & 39,0 & 39,0 \\
\cline { 2 - 5 } & female & 487 & 61,0 & 100,0 \\
\cline { 2 - 5 } & Total & 799 & 100,0 & \\
\hline
\end{tabular}




\section{Instruments}

The data collection instrument consisted of 29 easy-to-understand questions, elaborated with vocabulary adapted to elderly people. The questions were grouped into six dimensions: personal information about the centres; knowledge and access to senior centres; the centres' organizational structure schedule; type of activities available; the frequency of attendance; the degree of satisfaction with the healthy activities. A Likert Scale was applied, consisting of five values, to measure subjects perceptions. The questionnaire was validated by five experts, who assessed the dimensions and verified that the questions were formulated according to the objectives set. Reliability was calculated with Cronbach's Alpha, which returned a value of 0.821, considered acceptable [26], p. 231). Data were analyzed using the SPSS 24 statistical package.

\section{Plan and procedures}

Quantitative exploratory research was carried out, in view of understanding the relationship between certain variables (age, sex, information, attendance, schedule satisfaction, type of activity) and the degree of satisfaction with healthy activities. Daily

\section{Results \\ Descriptive Analysis}

The attendance to PE\&HA varies between age groups. The subjects report a low practice of healthy activities between the ages of 55 to 64 (2,7\% to 5,8\%), as we have seen before (Table 1). This practice takes its pick between 70 and 79 years of age $(27,5 \%$ to $27,6 \%)$ and then starts declining (Table 1).

About the PE\&HA it must be highlighted the following: Memory activities with $66(9,6 \%)$, Travels to Madrid, 57 cases (8,3\%); Ballroom dancing, 53 cases (7,7\%); and Laughter therapy, $44(6,4 \%)$ (Annexe 1).

Moreover, attendance also varies between sexes, we have found more females, 487 cases (61\%) in PE\&HA centres, than men, 312 cases (31\%) (Table 3).

Table 3. Attendance by Sexes

\begin{tabular}{|c|c|c|c|c|c|c|}
\hline \multicolumn{7}{|c|}{ Sex $*$ Attendance } \\
\hline \multicolumn{7}{|c|}{ Counting } \\
\hline & & \multicolumn{4}{|c|}{ Attendance } & \multirow[b]{2}{*}{ Total } \\
\hline & & daily & once a week & twice a week & once a month & \\
\hline \multirow[t]{2}{*}{ Sex } & Male & 99 & 132 & 50 & 31 & 312 \\
\hline & female & 142 & 122 & 193 & 30 & 487 \\
\hline \multicolumn{2}{|c|}{ Total } & 241 & 254 & 243 & 61 & 799 \\
\hline
\end{tabular}

Attendance once a week ( 254 cases, $31,8 \%$ ) is the most common form to take PE\&HA. Although, twice a week is also a very popular way to take PE\&HA (243 cases, 30,4\%). In this

respect, we watch a difference between males (50 cases, 6,25\%) and females (193 cases, $24,2 \%$ ). Daily PE\&HA is also very common (241 cases, 30,2\%). Here again, we see that females (142 cases, 17,8\%) report a higher degree of attendance regarding males (99 cases, $12,4 \%)$. Once a month is very similar to both sexes.

Similarly, we studied the degree of satisfaction of older adults in relation to PE\&HA carried out in the senior centres (Table 4). As can be seen in Table 4, participants aminly report "a lot of" satisfaction (480 caes, 60,1\%), whyle 314 caes $(39,3 \%)$ say they are quite satisfied.. 
Table 4. Degree of satisfaction with activities

\begin{tabular}{|c|l|r|r|r|}
\hline \multicolumn{4}{|c|}{ Satisfaction with PE\&HA } \\
\hline \multirow{2}{*}{} & f & $\%$ & $\%$ c \\
\hline \multirow{7}{*}{ Valid } & nothing & 3 &, 4 &, 4 \\
\cline { 2 - 5 } & quite & 314 & 39,3 & 39,7 \\
\cline { 2 - 5 } & a lot & 480 & 60,1 & 99,7 \\
\cline { 2 - 5 } & other & 2 &, 3 & 100,0 \\
\cline { 2 - 5 } & Total & 799 & 100,0 & \\
\hline
\end{tabular}

\section{Inferential Analysis}

In order to understand how the subjects get into programmes of active ageing, available in centres where a wide variety of educative and healthy activities are provided, we have considered the sexes and group ages preferences, the form of attendance, the type of activity and the reported satisfaction. Consequently, we stated six hypotheses, above mentioned.

Concerning the differences between age groups regarding the attendance to PE\&HA (H1), the Tukey HSD and the Scheffe tests (Lineal univariate model) returned very significant differences between the age group (Annexe 2). The group age 55-59 presents the lower degree of attendance regarding all the groups, except for the $>90$ age group.

About the differences between sexes regarding the attendance to PE\&HA $\left(\mathrm{H}_{2}\right)$, the $\mathrm{U}$ de Mann-Whitney and the Wilcoxon $\mathrm{W}$ also gave back very significant differences with advantage to females (Table 5). Women are more prone to look for PE\&HA, for reasons that are still to determine. Could it be a case of self-concept or gregariousness?

Table 5. Sexes vs. Attendance

\begin{tabular}{|l|r|}
\hline \multicolumn{2}{|c|}{ Test statistic } \\
\hline & Attendance \\
\hline U de Mann-Whitney & 66394,000 \\
\hline Wilcoxon W & 115222,000 \\
\hline Z & $-3,154$ \\
\hline Sig. (bilateral) &, 002 \\
\hline \multicolumn{2}{|l}{ a. Groupin variable: Sex } \\
\hline
\end{tabular}

As to the eventual differences between sexes regarding the type of PE\&HA $\left(\mathrm{H}_{3}\right)$, the Pearson $\mathrm{X}^{2}$ returned very significant differences, with highlight to, Memory activities with, Travels to Madrid, Ballroom dancing, Memory activities and Laughter therapy. Which indicates a broad range of preferences.

Table 6. Sexes vs. Attendance

\begin{tabular}{|l|l|c|}
\hline \multicolumn{3}{|c|}{ Pearson Chi-square } \\
\hline \multicolumn{2}{|c|}{} & Sex \\
\hline TypeActivity & $\mathrm{X}^{2}$ & 148,530 \\
\hline
\end{tabular}




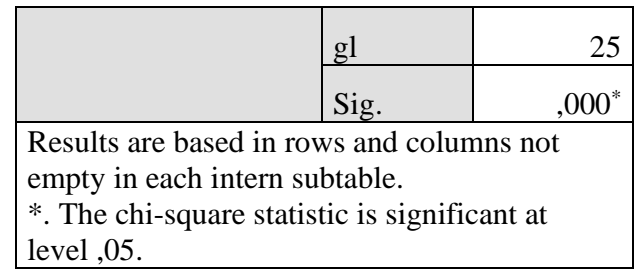

On the subject of differences between age groups regarding the type of activity attended, the Pearson $\mathrm{X}^{2}$ returned very significant differences, although the results may be invalid, as there were the were empty cells or cells count less than 5 (Table 7).

Table 7. Group Age vs. Attendance

\begin{tabular}{|c|c|c|}
\hline \multicolumn{3}{|c|}{ Pearson chi-square } \\
\hline & & Sex \\
\hline \multirow[t]{3}{*}{ TypeActivity } & Qui-quadrado & 148,530 \\
\hline & gl & 25 \\
\hline & Sig. &, $000^{*}$ \\
\hline \multicolumn{3}{|c|}{$\begin{array}{l}\text { Results are based in rows and columns not empty } \\
\text { in each intern sub-table. } \\
\text { *.The chi-square statistic is significant at level } \\
05 \text {. }\end{array}$} \\
\hline
\end{tabular}

The study found that there are significant differences between sexes regarding the reported satisfaction with PE\&HA (Table 8).

Table 8. Sexes vs. Satisfaction

\begin{tabular}{|l|r|}
\hline \multicolumn{2}{|c|}{ Estatísticas de teste $^{\mathrm{a}}$} \\
\hline & \multicolumn{1}{|c|}{ Satisfaction } \\
\hline U de Mann-Whitney & 71120,000 \\
\hline Wilcoxon W & 119948,000 \\
\hline Z & $-1,794$ \\
\hline Sig. (bilateral) &, 073 \\
\hline a. Grouping variable: Sex \\
\hline
\end{tabular}

In respect to the differences between age groups regarding the reported satisfaction with PE\&HA, the Tukey HSD and Scheffe tests (Lineal univariate model) also returned very significant differences between the age groups (Annexe 2). The group age 55-59 presents the lower degree of satisfaction regarding all the groups, except for the $>90$ age group.

\section{Conclusion}

The reader should take in consideration the limitations of this study. Namely, the lack of a randomized sample and appliance for the first time of an instrument elaborated ad hoc.

The extensive participation in PE\&HA carried out in senior centres reflects the satisfaction we encounter among the participants. This may allow achieving stable groups in order to plan new workshops in the coming years. Such practices, aside from being a factor of socialization, may generate great personal enrichment, through learning cooperatively.

Regarding the results of the study, it was observed that women were more participatory and open to learning as they found benefits for their personal development, although it has to be noted that the activities carried out at the centre were more related to women than to men. In relation to this finding, Pinzón, Bustos \& Herrera (2017) also refer greater participation of a group of 170 older adults' women, in a study that aimed to identify their occupational interests and expectations in social participation. Moreover, Montero, Mínguez \& Bedmar (2011) reported greater participation of elderly women in activities that stimulate leisure and 
entertainment as a strategy for the active development of this stage of life. Therefore, it is necessary to implement specific strategies to obtain more male participation in the workshops, as their absence deprives them of receiving a series of benefits such as: the pleasure of learning, feeling motivated, self-satisfaction, being up to date with new technologies, and improve their quality of life.

On the other hand, the older adults who participated in the study showed interest in several of the activities that take place in the senior centres. This is the case regarding excursions and celebrations. These findings confirm the results of Fernández (2011), which reported that in Spain, much of the elderly perceived ageing in a positive way when carrying out activities related to sharing with their peers and family. Therefore, the involvement of loved ones can be an important factor in understanding the enjoyment that older adults experience in each activity they participate in, which in turn is evidenced by the increased frequency of participation in the activities programmed in the centres.

In Fernández (2011) study, 90\% of the elderly who participated in active ageing programs were satisfied with their family relationships and $78.8 \%$ were satisfied with their friendly relationships; besides they felt safe and confident with the people around them. This agrees with what is explained by Abellán \& Esparza (2009), who stated that the ageing process should not be a problem, but a challenge for everyone, both for society and the ageing individual.

Urquiio, Monchietti \& Krzemien (2008) concluded that older adults who use active, cognitive, and behavioural coping strategies improve their quality of life and explore alternatives for action to overcome the obstacles they face in life; whereas those with personality styles characterized by preservation, accommodation, and protection are generally interested in meeting the needs of others and are prudent, reserved, and not intending to actively intervene in the course of events. In this research, we identified a high frequency of participation of older adults in the activities promoted in the senior centres, which would represent, according to Urquiio, Monchietti \& Krzemien (2008), a positive coping and the guarantee of a higher quality of life.

This would explain the high satisfaction experienced by a part of this group, as according to the results of the questionnaire applied by Monteagudo, García \& Ramos (2016), about 78\% of older adults state that participation in workshops and other group activities contribute to improving their quality of life. The same authors also indicate that older people can prevent dependency through active ageing programs that promote quality of life (Monteagudo, García \& Ramos, 2016). In fact, older adults can actively age by taking the initiative to participate in intergenerational programs (Teater, 2016).

When there is a negative perception of old age, the opposite effect occurs, as demonstrated by Levy \& Myers (2004), who, after carrying out several experimental and longitudinal studies in older people, concluded that negative stereotypes about old age influence memory, cause stress and poor coping strategies and even predict less longevity. However, the findings of this research show a weekly and daily frequency of attendance at the senior centre and participation in active ageing activities, producing an effect contrary to that found by Levy \& Myers (2018). Therefore, our results could be equivalent to those found by Pedrero, Moreno \& Moreno (2018) who showed in their study that older people who face ageing positively enjoyed better functional health than those who had a more negative opinion. The results of this study answered the general objective and the research questions raised. The study focused on the opinions of older adults, through a questionnaire that gave different evaluations regarding the activities carried out in the senior centres. 
Regarding active ageing, it was observed that participation in workshops improves selfesteem and family relationships, and expands new social relationships. The reinforcement of social, emotional skills and cultural training as a guide in leisure time highlights the importance of non-formal education for leisure and free time.

On the other hand, it became clear that the activities promoted by the senior centres that were part of this study facilitate all the training programmes designed for the elderly, ranging from competencies related to active ageing to concern for the development of quality of life, which represented a common concern of agencies and specialized professionals.

Regarding the participation of older adults in the activities that are programmed in the senior centres as part of active ageing programs, regular participation of male subjects was observed, although being lower than females. So being it is recommendable that more favourable results be obtained through programmes that can attract men to PE\&HA. Therefore, we consider it important to guarantee the opportunities and spaces necessary for the enjoyment of leisure activities that take into account the interests of men, which would guarantee a complete service that promotes satisfaction, motivation and learning into both men and women.

Likewise, regarding the general objective of this study, the relationship between the high frequency of participation of the elderly in the activities programmed by the senior centre and the satisfaction experienced, indicate the importance of these activities in increasing quality of life of the elderly. it is necessary to guarantee access to services offered by senior centres to promote well-being and happiness in this age group.

Similarly, the need to continue deepening the requirements of older adults in relation to their participation in active ageing programs is evident. This study contributes to the line of research on understanding the care needs of older adults during their stay in specialized senior centres. However, it is necessary to address the satisfaction and frequency of participation in active ageing activities in future studies, which should take into account important variables such as the timing of the options and perceptions of the group that makes up the sample. In this way, the changes that occur regarding satisfaction and the number of times that older adults participate in recreational activities could be studied through a timeline.

With this limitation, this study only allows addressing the results obtained considering a single moment. However, the data that was obtained constitutes an important advance given the current interest of researchers in the concept of active ageing

\section{References}

[1]. United Nations (UN). Ideas clave del informe "Perspectivas de la población mundial 2019"(en español). 2020. Available at: https://www.un.org/es/sections/issues-depth/ageing/index.html. Accessed: February 29, 2020

[2]. Van Leeuwen KM, Van Loon M S, Van Nes FA, Bosmans JE, De Vet HC, Ket JC, Ostelo RW. What does quality of life mean to older adults? A thematic synthesis. PloS one. 2019, 14(3). https://doi.org/10.1371/journal.pone.0213263

[3]. Fernández-Ballesteros R. Envejecimiento activo, Madrid, Spain: Pirámide, 2009.

[4]. Rodríguez G. Las personas mayores que vienen. Autonomía, solidaridad y participación social. Madrid, España: Fundación Pilares, 2013.

[5]. Fernandez-Ballesteros R, Olmos R, Santacreu M, Bustillos A, Molina MA. The role of perceived discrimination on active ageing. Arch Gerontol Geriatr. 2017; 71, 14-20.

[6]. Dumitrache CG, Rubio L, Bedoya I, Rubio-Herrera R. Promoting Active Ageing in rural Settings: an Intervention Program Implemented in Orense, Spain. Univ. Psychol. 2017, 16(3), 112-123. 
[7]. Fernández-Ballesteros R. Limitaciones y posibilidades de la edad. IMSERSO. Libro Blanco del envejecimiento activo; 2011. p. 113-148.

[8]. Caprara M, Molina M Á, Schettini R, Santacreu M, Orosa T, Mendoza-Núñez VM, et al. Active ageing promotion: results from the Vital Ageing Program. Curr Gerontol Geriatr Res, 2013.

[9]. Pérez Pérez I, Valero X, Alcántara A, López Teulón MP. Asociacionismo, participación y animación sociocultural: el caso ANRIE_ASC. Quaderns d'animació i educació social. Revista semestral para animador@sy educador@s sociales. 2020, núm. 31, p. 1-15.

[10]. Reina M. Los cuatro pilares de la educación. Con-Ciencia Boletín Científico de la Escuela Preparatoria. 2020; 3, 7(13), 11-15.

[11]. Delors J. La educación encierra un tesoro. Madrid: Santillana. Ediciones UNESCO; 1996

[12]. Águila C. Sobre el ocio y la posmodernidad, Wanceulen, Sevilla; 2007

[13]. Breheny M, Stephens C. Spending time: The discursive construction of leisure in later life. Ann. Leis. Res. 2017, 20(1), 39-54.

[14]. Barnés P. El asociacionismo de las mujeres en la Región de Murcia. Murcia, España: Consejería de Presidencia; 2005

[15]. Gu MK. Factors Affecting the Participation in Leisure Activities by Elderly Women Living Alone. J Korean Acad Community Health Nurs. 2018; 29(3), 257-266.

[16]. Zieliński A. Ageing individuals and ageing populations. Przegl Epidemiol. 2015; 68(3), pp. 399404.

[17]. Bruno F, Alemán JA. Vejez y sociedad en México: Las visiones construidas desde las Ciencias Sociales. In Forum Sociológico. 2016, Série II (No. 29). CESNOVA.

[18]. De Haro AE, de Miguel López SM, Aroca JAS. La percepción de la calidad de vida en las mujeres mayores y su envejecimiento activo a través de actividades socioeducativas en los centros sociales. Revista de Investigación Educativa. 2015, 33(2), 471-488. https://doi.org/10.6018/rie.33.2.213211

[19]. Hernández Rodríguez G. "Jubilación y alternativas para un ocio creativo", en J. Giró, (coord.), Envejecimiento, tiempo libre y gestión del ocio, Universidad de La Rioja, Logroño, 2009.

[20]. Ley 39/2006, de 14 de diciembre, de Promoción de la Autonomía Personal y Atención a las personas en situación de dependencia. Boletón Oficial del Estado, núm. 299, de 15 de diciembre de 2006

[21]. World Health Organization. Active ageing: A policy framework (No. WHO/NMH/NPH/02.8). Geneva: World Health Organization, 2002.

[22]. Abellán A, Esparza C. Percepción de los españoles sobre distintos aspectos relacionados con los mayores y el envejecimiento. Madrid: IMSERSO; 2009

[23]. Limón M, Chalfoun M. La Biblioteca como agente social en el proceso de empoderamiento de los adultos mayores en un ambiente intergeneracional e intercultural. Congreso Internacional de Pedagogía Social. Libro de Actas y Resúmenes. Editorial Copiarte: Sevilla, 2017.

[24]. Escotorin P, Roche R. Cómo y por qué prosocializar la atención sanitaria: reflexiones, desafíos y propuestas. Conclusiones del Proyecto Europeo CHANGE. La Garriga: Edicions Fundació Martí L'Humà; 2011

[25]. Lobo, A., Saz, P., \& Marcos, G. (2002). Adaptación del Examen Cognoscitivo Mini-Mental [Adaptation of Mini Cognoscitive Exam]. Madrid, Spain: Tea Ediciones

[26]. George D, Mallery P. SPSS for Windows Step by Step: A Simple Guide and Reference. 11.0 Update, Allyn \& Bacon, Boston, Mass, USA, 4th edition, 2003.

[27]. Teater B. Intergenerational programs to promote active ageing: The experiences and perspectives of older adults. Activities, Adaptation \& Ageing. 2016; 40(1), 1-19. https://doi.org/10.1080/01924788.2016.1127041

[28]. Pinzón EY, Bustos SCC, Herrera MJM. Intereses de ocio y tiempo libre de los adultos mayores del municipio de Guachucal, Nariño. Revista Unimar. 2017; 35, 151-162.

[29]. Montero I, Mínguez G J, Bedmar M. Ciudadanía activa y personas mayores. Contribuciones desde un modelo de educación expresiva. Revista Iberoamericana de Educación. 2011, 55(5).

[30]. Urquijo S, Monchietti A, Krzemien D. Adaptación a la crisis vital del envejecimiento: Rol de los estilos de personalidad y de la apreciación cognitiva en adultas mayores. An. Psicol. 2008, 24(2), 299-311. 
[31]. Monteagudo AM, García MY, Ramos M. El envejecimiento activo: importancia de su promoción para sociedades envejecidas. Revista Archivo Médico de Camagüey. 2016; 332.

[32]. Levy BR, Myers LM. Preventive health behaviors influenced by self-perceptions of ageing. Prev. Med. 2004; 39(3), 625-629. https://doi.org/10.1016/j.ypmed.2004.02.029

[33]. Pedrero-García E, Moreno-Crespo P, Moreno-Fernández O. Sexualidad en Adultos Mayores: Estereotipos en el Alumnado Universitario del Grado de Educación Primaria. Formación universitaria. 2018; 11(2), 77-86. 